\title{
Review of the Topics
}

\section{in the Reading and Writing}

\section{Journal}

\author{
Semih Topal \\ Uşak University \\ semihtopalage@gmail.com \\ ORCID:0000-0001-5954-6006
}

\section{Erol Duran}

Uşak University

erol.duran@usak.edu.tr

ORCID:0000-0001-7581-3821
Received : March 25, 2021

Revised :May 3, 2021

Accepted:June 1, 2021

Okuma Yazma Eğitimi Araștırmalar 2021, 9(1), 34-44 Research in Reading \& Writing Instruction, 2021, 9(1), 34-44 Doi: 10.35233/oyea.903471

\begin{abstract}
The aim of this study was to determine which concepts are focused on in article titles published in the well-known literacy journal "Reading and Writing". For this purpose, "What are the most common phrases and words in the article titles published in Reading and Writing journal in the last 5 years?" The answer to the question was sought. The research is in the content analysis pattern. In the study, the volumes of the journal belonging to the last 5 years were examined. Documentary analysis technique was used for data collection. The specified volumes and issues of the journal were accessed from the internet database. The most frequently used words and word groups were determined by scanning the identified article titles with the help of a word search program (Wordcounter) and their frequencies were specified. Descriptive statistics were used in data analysis. As a result of the research, it was seen that the most common concepts in the scanned 483 article titles were reading comprehension, morphological awareness, word reading, fluent reading, and second language, respectively. In word form, the most frequently used concepts were found to be reading, writing, child, comprehension and language, respectively. In addition, the findings indicated that there are changes over the years, and studies on certain concepts have become more prominent in some years. Information was given on some of the word groups that attracted attention. In the light of these results, it is thought that the data obtained are important in terms of showing which concepts have been focused on in the field of reading and writing in the world in recent years, and in this respect, it will give researchers an idea about the topics of study they can do.
\end{abstract}

Keywords: Reading and Writing journal, topics, reading, writing.
$\mathrm{R}$ eading and Writing Journal, which started its publication life in 1989, is among the world-renowned journals in the field of literacy education. The journal is published under the editorship of R. Malatesha Joshi, affiliated with the Springer publishing house. Focusing on research based on the interaction of various sciences such as linguistics, information processing, neuropsychology, cognitive psychology, speech / auditory science and education with an interdisciplinary approach, this journal offers high-quality research, criticism, theoretical articles and case studies on processes, acquisitions and disorders in reading and writing skills studies are included (Springer, 2021).

This study aims to determine which concepts are included more frequently at the level of words and phrases in article titles published in the journal "Reading and Writing" in the last five years. In this way, it has been tried to determine which concepts and subjects are emphasized in the studies published in the journal in the last five years. In addition to the holistic evaluation of the obtained data, data analysis was performed separately by years, and it was tried to determine whether the word phrases frequently included in the titles changed by years or not. In this respect, it is thought that the research will help researchers who will study in the field to gain ideas in determining the subject. 


\section{Method}

\section{Model}

This study, which aims to determine which concepts are focused on in article titles published in "Reading and Writing" journal, was prepared with content analysis. Purposeful sampling was used in determining the articles.

\section{Articles Reviewed}

In the study, articles belonging to the last 5 years of "Reading and Writing Journal" were determined. The reason for choosing this journal is that it is among the journals with the highest citations in the fields of educational research and educational psychology, according to Web of Science 2020 data. Publications in this journal, which is included in the 2020 International Scientific Publications Encouragement journal list published by TÜBİTAK in Turkey, are encouraged. The Article Impact Score regarding the incentives was reported as 0.868 (ULAKBİM, 2021).

\section{Data Analysis}

Descriptive statistics were used as data analysis. Descriptive statistics; It is based on presenting the findings according to the determined statistical measures. It is aimed to summarize the obtained data and to classify them according to certain characteristics (Balcı, 2010; Büyüköztürk et al., 2012).

\section{Findings and Conclusion}

In this study, we tried to identify the most frequently used word groups and words in the article titles published in the journal "Reading and Writing" in the last five years. In this way, it has been tried to determine which concepts and subjects the journal has focused on in the studies published in the last five years. A total of 483 article titles were examined and the word groups and the frequencies of the words in these article titles were determined. It has been observed that the studies in the journal are compatible with the fields covered by the journal in accordance with the journal's interdisciplinary approach. When the data obtained were examined, it was seen that the most frequently repeated phrases in the titles of the journal in the last five years were "Reading comprehension (f: 56)", "Morphological awareness (f: 22)" and "Word reading (f: 17)", respectively. From this point of view, it is seen that in the studies on literacy published in the journal in the last five years, researchers have significantly focused on "reading comprehension" skills. It can be commented that because the reading comprehension skill affects and determines all of the student's learning throughout his life, researchers concentrate on studies aimed at this. In addition, it was found that articles published in the last five years included more studies at primary school level than other levels. This differentiation is thought to occur because of the critical importance of the primary school period in the acquisition of reading and writing skills.

When examined in terms of vocabulary, it has been observed that the studies published in the journal do not have equal coverage of reading and writing skills. Based on the published article titles, it was seen that the journal gives more place to studies for reading.

When the data obtained were analyzed by years, it was seen that some word groups were included in article titles more in certain years than in other years. For example, in 2016, "Dictionary quality", "Resource information"; In 2018, "The reader with difficulties", "Linguistic knowledge", "Metalinguistic knowledge of more than one language; In 2019, "Writing Difficulties", "The reader with difficulties"; In 2020, it was determined that "Emergent literacy" word groups were more frequently used in headings than in other years. From this point of view, it can be said that the concepts discussed in the articles in the journal differ according to years. 


\section{Reading and Writing Dergisindeki Konu Başlıklarının İncelenmesi}

\author{
Semih Topal \\ Uşak Üniversitesi \\ semihtopalage@gmail.com \\ ORCID:0000-0001-5954-6006
}

\section{Erol Duran}

Uşak Üniversitesi

erol.duran@usak.edu.tr

ORCID:0000-0001-7581-3821

\begin{abstract}
ÖZET
Bu çalışmanın amacı okuma yazma alanında tanınmış olan "Reading and Writing" dergisinde yayımlanmış olan makale başlıklarında hangi kavramlara odaklanıldığını tespit etmektir. Bu amaç doğrultusunda "Reading and Writing dergisinde son 5 yll içerisinde yayımlanan makale başlıklarında en sık geçen sözcük grupları, sözcükler nelerdir?" sorusuna yanıt aranmıştır. Araştırma içerik analizi desenindedir. Çalışmada derginin son 5 yllına ait ciltleri incelenmiştir. Verileri toplamak için İnternet veri tabanından derginin belirtilen cilt ve sayılarına ulaşılmıştır. Tespit edilen makale başlıkları sözcük tarama programı (Wordcounter) yardımıyla taranarak en sık kullanılan sözcük, sözcük grupları belirlenmiş ve frekansları belirtilmiştir. Veri analizinde betimsel istatistik kullanılmıştır. Araştırma sonucunda taranan 483 makale başlığında en sık yer alan kavramların sözcük grubu biçiminde sırasıyla okuduğunu anlama, morfolojik farkındalık, sözcük okuma, akıcı okuma, ikinci dil olduğu görülmüștür. Sözcük biçiminde ise en sık kullanılan kavramların sırasıyla okuma, yazma, çocuk, anlama ve dil sözcükleri olduğu görülmüştür. Ayrıca yıllara göre değişimler olduğu, belirli kavramlara yönelik çalışmaların bazı yıllarda daha çok öne çıktığı görülmüştür. Dikkati çeken bazı sözcük grupları hakkında da bilgilendirme yapılmıştır. Bu sonuçlar ışı̆̆ında elde edilen verilerin, dünyada okuma ve yazma alanında son yıllarda hangi kavramlara odaklanıldığ bakımından önemli olduğu ve bu yönüyle araştırmacılara yapabilecekleri çalışma konuları hakkında fikir vereceği düşünülmektedir.
\end{abstract}

Anahtar kelimeler: Reading and Writing dergisi, konu başlıkları, okuma, yazma.
GelişTarihi $\quad$ :25 Mart 2021
Düzeltme Tarihi : 3 Mayıs 2021

$\begin{array}{ll}\text { Düzeltme Tarihi } & : 3 \text { Mayıs } 2021 \\ \text { Kabul Tarihi } & : 1 \text { Haziran } 2021\end{array}$

Okuma Yazma Eğitimi Araștırmaları, 2021, 9(1), 34-44 Research in Reading \& Writing Instruction, 2021, 9(1), 34-44 Doi: 10.35233/oyea.903471
$\mathrm{Y}$ ayın hayatına 1989 yılında başlamış olan "Reading and Writing" dergisi okuma yazma eğitimi alanında dünya çapında tanınmış dergiler arasında yer almaktadır. Dergi R. Malatesha Joshi editörlüğünde Springer yayınevine bağlı olarak yayımlanmaktadır. Disiplinler arası bir yaklaşımla dilbilim, bilgi işleme, nöropsikoloji, bilişsel psikoloji, konuşma/ işitme bilimi ve eğitimi gibi çeşitli bilimlerin etkileşimine dayanan araştırmalara odaklanmış olan bu dergide okuma ve yazma becerilerinde süreç, edinim ve bozukluklara ilişkin yüksek kalitede araştırma, eleştiri, kuramsal makalelere ve vaka çalışmalarına yer verilmektedir (Springer, 2021).

Okumak eylemi Türkçe Sözlük'te (Türk Dil Kurumu, 2005:1494) "Yazıya geçirilmiş bir metne bakarak bunu sessizce çözümleyip anlamak veya aynı zamanda seslere çevirmek." olarak tanımlanmıştır. Birçok kişi tarafından yapılmış olan tanımlamalarda bazı farklılıklar olsa da okumanın bir algılama ve kavrama süreci olduğu yönünde ortak bir kabul oluştuğu görülmektedir (Arıcı, 2008, Baştuğ, Hiğde, Çam, Örs ve Efe, 2019, Razı, 2008, Savaş, 2006; Uslu Üstün, 2019). Okuma eylemi harfleri, kelimeleri ve cümleleri seslendirmekle ve birbirini takip eden kelimeleri tanımakla sınırlı değildir. Okuma eyleminin beceriye dönüşmesi için anlamanın gerçekleşmesi gerekir. Dolayısıyla bu beceriyi edinmiş olan okuyucudan beklenen, metni kendi deneyim ve yaşantılarıyla da ilişkilendirmesidir. Modern dünyada da dil öğrenmekten sonra en 
önemli beceri okuma-yazma öğrenmek ve bunu başarılı bir biçimde kullanabilmektir (Aytaş, 2005; Fischer, 2020).

Okullarda ilk yıllar çocuklar için okumayı öğrenme yıllarıdır. Özellikle birinci sınıfta öğrenciler okumayı öğrenme üzerine okumalar yapar. Sınıf düzeyi arttıkça okumanın şekli ve amacı da değişmektedir. Başlangıçta amaç okumayı öğrenmek iken daha sonraki ylllar farklı türdeki materyallerden bilgi edinme, öğrenmeye dönüşmektedir. Okuma sürecinin önemli bir eylemi olan anlama becerisi kritik bir öneme sahiptir. Çocuk okumayı öğrenmekle birlikte metinlerde yazılanları anlamaya çalışır. Bu süreç de anlam kurma süreci olarak yorumlanır. Bu nedenle de okuma eylemi ile anlama becerisi birlikte gelişmektedir ve okuma çalışmaları anlama çalışmalarından bağımsız düşünülmemelidir (Aytaş, 2003; Baştuğ vd., 2019; Coşkun, 2002; Henniger, 2005; Özbay ve Memiş, 2015; Özge, 2016; Yıldız, 2003).

İnsanoğlu, sınırsı düşünceler zincirini dile getirmek için sınırlı sayıda araca sahiptir. Bunu fark eden Galileo da "Dialogo" adlı yapıtında "Altı üstü yirmi dört tanecik harfin kâğı üzerinde farklı şekillerde yan yana dizilmesiyle en gizli düşüncelerini ifade etmelerini sağlayan bir iletişim aracının keşfini” hayranlıkla anlatmıştır. Galileo burada alfabetik yazıdan söz ediyordu. İnsanlık kendi gelişimi içerisinde elbette baştan beri modern anlamda yazı yazmaya başlamamıştır. Hatta hâlâ yazı kullanmayan birçok kültür de bulunmaktadır. Ancak bugünkü modern medeniyet yazıya dayanmaktadır. Bilginin patlaması ve yeni gelişmelerin, fikirleri yazıya geçirme sayesinde gerçekleşmiş̧ir. Yazı sadece konuşma dilini korumakla kalmaz. Aynı zamanda kapsamlı toplumsal sonuçları olan dil odaklı birçok süreci düzenler, standartlaştırır, yönlendirir, zenginleştirir ve yaratır (Chomsky, 2016; Coşkun, 2013; Ergin, 2011; Fischer, 2020; Temizkan, 2010; Trabant, 2020).

Her ne kadar anlam cümle temelinde oluşmakta ise de bu yapıyı oluşturan sözcükler ve sözcük grupları da önemlidir. Kelimelerdeki anlamsal değişmeler, kullanımı artan kelimeler, kullanımdan düşen kelimeler bizlere toplumun düşünce yapısından yücelttiği değerlere, ilgi duyduğu konulara kadar çok geniş bir alanda ipuçları sunar (Baddeley, Thomson ve Buchanan, 1975; Dilidüzgün, 2014; Karadüz, 2009; Morton, 1969; Sav, 2003; Thornbury, 2013). Bu nedenle alanla ilgili Reading and Writing dergisinde yayımlanan çalışmaları yakından takip etmek, odaklanılan kavramları tespit etmek ve yıllara göre ağırlık verilen kavramlarda değişikliğin olup olmadığını araştırmak için böyle bir çalışmaya ihtiyaç duyulmuştur.

Yukarıda yapılan değerlendirmelerden hareketle bu çalışma "Reading and Writing" dergisinde son beş yıl içerisinde yayımlanan makale başlıklarında sözcük ve sözcük grupları düzeyinde hangi kavramlara daha sık yer verildiğini belirlemeyi amaçlamaktadır. Bu yolla dergide son beş yll içinde yayımlanan çalışmalarda hangi kavramlara, konulara ağılık verildiği tespit edilmeye çalışılmıştır. Ayrıca elde edilen veriler bütünsel değerlendirmeye ek olarak yıllara göre göre ayrı ayrı veri analizi yapılmış ve başlıklarda sıklıkla yer alan sözcük öbeklerinin yıllara göre değişim gösterip göstermediği belirlenmeye çalışılmıştır. Bu yönüyle araştırmanın, alanda çalışma yapacak araştırmacılar için konu tespitinde fikir edinmelerine yardımcı olacağı düşünülmektedir.

Bu bağlamda çalışmanın alt problemleri ise şunlardır: Reading and Writing dergisinde

1. Son beş yıl içerisinde yayımlanmış olan makale başlıklarında en sık yer alan sözcük grupları nelerdir?

2. Son beş yıl içerisinde yayımlanmış olan makale başlıklarında en sık yer alan sözcükler nelerdir?

3. 2016 Yılı içerisinde yayımlanmış olan makale başlıklarında en sık yer alan sözcük grupları nelerdir?

4. 2017 Yılı içerisinde yayımlanmış olan makale başlıklarında en sık yer alan sözcük grupları nelerdir?

5. 2018 Yılı içerisinde yayımlanmış olan makale başlıklarında en sık yer alan sözcük grupları nelerdir?

6. 2019 Yllı içerisinde yayımlanmış olan makale başlıklarında en sık yer alan sözcük grupları nelerdir?

7. 2020 Yılı içerisinde yayımlanmış olan makale başlıklarında en sık yer alan sözcük grupları nelerdir?

\title{
Yöntem
}

\begin{abstract}
Model
"Reading and Writing" dergisinde yayımlanmış olan makale başlıklarında hangi kavramlara odaklanıldığını belirlemeyi amaçlayan bu çalışma içerik analizi ile hazırlanmıştır. İçerik analizi, elde edilen verilerin, kodlama, sınıflama yoluyla yorumlanmasına yönelik çalışmalarda kullanılmaktadır. Bu yolla çalışmada elde edilmiş olan uzun ve karmaşı verilerden anlamlı temalar ortaya çıkarılabilmektedir (Balcı, 2010, Cansoy ve Türkoğlu, 2019; Fraenkel ve Wallen, 2006).
\end{abstract}

\section{İncelenen Makaleler}

Makalelerin belirlenmesinde amaçsal (amaçlı) örnekleme başvurulmuştur. Amaçsal örnekleme, araştırmacının amacına en fazla hizmet edeceğini düşündüğü çalışmalara odaklanmasını sağlar. Belirlenmiş olan özel durumlarda çalışma yapılmak istenildiğinde bu örnekleme yöntemine başvurulabilir (Büyüköztürk vd., 2012).

Çalışmada Reading and Writing dergisinin son 5 yılına ait (29-33 cilt arası kadar) 5 cilt belirlenmiştir. Bu derginin seçilmesinin nedeni Web of Science 2020 (Master Journal List, 2021) verilerine göre, eğitim araştırmaları ve eğitim 
psikolojisi alanlarında en yüksek alıntılamaya sahip dergiler arasında yer almasıdır. Ülkemizde de TÜBİTAK tarafından yayımlanmış 2020 UBYT (Uluslararası Bilimsel Yayınları Teşvik) dergi listesinde yer almakta olan bu dergide yer alan yayınlar teşvik edilmektedir. Teşvike ilişkin MEP (Makale Etki Puanı) 0.868 olarak belirtilmiştir (ULAKBİM, 2021).

Springer yayınevi bünyesindeki "Reading and Writing” dergisi 1989 yılında yayın hayatına başlamıştır. Okuma ve yazma becerilerinde süreç, edinim ve bozukluklara ilişkin yüksek kalitede araştırma, eleştiri, kuramsal makalelerin ve vaka çalışmalarının yer aldığı bir dergidir. Dergi disiplinler arası bir yaklaşımla dilbilim, bilgi işleme, nöropsikoloji, bilișsel psikoloji, konuşma ve ișitme bilimi ve eğitimi gibi çeșitli bilimlerin etkileșimine dayanan araştırmalara odaklanmıştır. Derginin editörü R.Malatesha Joshi’dir (Springer, 2021).

Belirlenen ciltlerde toplam 483 makale başlı̆̆ı yer almaktadır. Makalelerde anahtar kelime sayısı beş ile sınırlı tutulması sebebiyle bu çalışmada daha zengin veriye ulaşmak için makale başlıkları tercih edilmiştir. Bu makale başlıklarında toplam 6.649 sözcük bulunmaktadır. Yıllara göre dergide yayımlanan makale sayısı şöyledir:

2016 (Cilt 29): 86 makale, 2017 (Cilt 30): 96 makale, 2018 (Cilt 31): 93 makale, 2019 (Cilt: 32): 99 makale ,2020 (Cilt 33): 109 makale

\section{Verilerin Toplanması}

Veri toplama aracı olarak belgesel tarama (doküman metodu) kullanılmıştır. Kayıt ve verileri inceleme yoluyla veri elde etme yöntemidir. Bu yöntemde kaynaklar taranarak not alma ve fişleme yapılarak değerlendirmede bulunulur (Karasar, 2012; Özkan, 2019). Veri toplama aşamasında Reading and Writing dergisinde son 5 yıl içinde yayımlanan makale başlıkları ele alınmıştır. Derginin internet veri tabanından ilgili derginin belirtilen cilt ve sayılarına ulaşılmıştır. Çalışmaya konu olan bu beş ciltte yer alan makale başlıkları tespit edilerek ait oldukları cilt numarasına uygun olarak sıralanmıştır. Tespit edilen makale başlıkları sözcük tarama programı Wordcounter yardımıyla taranarak en sık kullanılan sözcük ve sözcük grupları belirlenmiş, karşılarına frekansları belirtilmiştir. Güvenirlik için bu programdan elde edilen veriler Word programı ile doğrulanmıştır.

\section{Verilerin Analizi}

Veri analizi olarak betimsel istatistik kullanılmıştır. Betimsel istatistik; elde edilen bulguları, belirlenen istatistikî ölçülere göre ortaya koymaya dayanmaktadır. Elde edilen verilerin özetlenmesi ve belirli özelliklere göre ayrılması, sınıflanması amaçlanır (Balcı, 2010; Büyüköztürk vd., 2012). Yorumlama aşamasında ise frekans tablosundan yararlanılmıștır. Frekans tablosu veri setlerini özetlemek ve değişkenlere ait değerler setinin sıklığını ortaya koymada kullanılmaktadır (Cansoy ve Türkoğlu, 2019).

Verilerin analizinde Wordcounter sözcük tarama programı ve Microsoft Word programları kullanılmıştır. Wordcounter programı yardımıyla, toplanan makale başlıklarında en sık tekrarlanan otuz sözcük grubu ve otuz sözcük frekanslarıyla birlikte belirlenmiştir. Sözcüklerin veya sözcük gruplarının başlıklardaki tekrar sayısı frekans değeri altında belirtilmiştir. Ardından frekans değeri yüksekten düşüğe olacak biçimde sözcük grubu ve sözcük biçimindeki ilk otuz kavramın sıralaması ayrı tablolar hâlinde gösterilmiştir. Yıllara göre makalelerde yer alan sözcük gruplarında değişimlerin incelendiği tablolarda ise bu sayı on ile sınırlı tutulmuştur. Güvenirlik için elde edilen frekans verileri Word programı aracılığıyla kontrol edilmiştir. Her iki programda da eş sonuçlara ulaşıldığ

\section{Bulgular}

"Reading and Writing” dergisinde yayımlanmış olan makale başlıklarında hangi kavramlara odaklanıldığını tespit etmeyi amaçlayan bu çalışmada elde edilen bulgular araştırmacı tarafından alt problemlere göre tablolar hâlinde sunulmuştur.

Araştırmada ilgili dergide son beş yıl içerisinde (Cilt 29-33) yayımlanan toplam 483 makale tespit edilmiştir. Bu makalelerin 109'u 2020, 99'u 2019, 93'ü 2018, 96’sı 2017, 86’sı 2016 yılında yayımlanmıştır.

\section{Birinci Alt Amaca İlişkin Bulgular}

Araştırmanın birinci alt amacına ilişkin bulgular Tablo 1'de sunulmuştur. Tablo incelendiğinde dergide yer alan 483 makale başlığında toplam 6.649 sözcüğün kullanıldığı tespit edilmiştir. Derginin son beş yıl içerisinde yayımlanan makalelerinde en çok tekrar eden sözcük gruplarının sırasıyla okuduğunu anlama, morfolojik farkındalık ve sözcük okuma olduğu tespit edilmiştir. Makale başlıklarında en çok tekrar eden sözcük gruplarının gösterildiği Tablo 1 incelendiğinde dergide son beş yıl içerisinde yayımlanan makale başlıklarında okuduğunu anlamaya yönelik çalışmalara belirgin bir biçimde daha fazla eğilim gösterildiği gözlenmektedir. Bunun sebebinin okuduğunu anlama becerisinin dil becerileri içerisinde en önemli becerilerden biri olduğu düşünülmektedir. Bundan yola çıkılarak da derginin, araştırmacıların bu beceriyi diğerlerine göre daha ön planda tuttukları yorumu yapılabilir. Ayrıca çalışma grubu olarak ilkokul düzeyinde öğrencilerin belirlendiği çalışmaların da diğer öğretim kademelerinde uygulanan çalışmalardan daha fazla sayıda olduğu görülmektedir. Buradan okuma yazma eğitiminde ilkokul birinci ve ikinci sinıf düzeyinin kritik bir 
öneme sahip olduğu ve bu nedenle bu sınıfların düzeyinde yapılan çalışmalara ağırlık verildiği yorumu yapılabilir. Buna ek olarak dergide yer alan çalışmaların da derginin kapsadığı alanlarla uyumlu olduğu gözlenmiştir.

\section{Tablo 1}

Son Beş Yıl İçinde Makale Başlıklarında En Sık Yer Alan Sözcük Grupları

\begin{tabular}{|c|c|c|c|}
\hline Sözcük Grubu & f & Sözcük Grubu & $\mathbf{f}$ \\
\hline Reading comprehension (Okuduğunu anlama) & 56 & Oral reading (Sesli okuma) & 8 \\
\hline Morphological awareness (Morfolojik farkındalık) & 22 & Academic language (Akademik dil) & 8 \\
\hline Word reading (Sözcük okuma) & 17 & Middle school (Ortaokul) & 7 \\
\hline Reading fluency (Akıcı okuma) & 13 & Early reading (Erken okuma) & 7 \\
\hline Second language (İkinci dil) & 12 & Emergent literacy (İlk ortaya çıkan okuryazarlık) & 7 \\
\hline First grade (Birinci sınıf) & 11 & Writing quality (Yazı kalitesi) & 7 \\
\hline Executive functions (Yürütücü fonksiyonlar) & 10 & Chinese children (Çinli çocuklar) & 7 \\
\hline Text structure (Metin yapısı) & 10 & Language skills (Dil becerileri) & 7 \\
\hline Language learner (Dil öğrenici) & 10 & Struggling reader (Güçlük çeken okur) & 6 \\
\hline Phonological awareness (Fonolojik farkındalık) & 9 & Teaching writing (Yazma öğretimi) & 6 \\
\hline Children's reading (Çocukların okuması) & 9 & Written composition (Kompozisyon yazma) & 6 \\
\hline Working memory (Kısa süreli bellek) & 9 & Vocabulary knowledge (Sözcük bilgisi) & 6 \\
\hline School student (Okul öğrencisi) & 8 & Elementary student (İlkokul öğrencisi) & 6 \\
\hline Reading and writing (Okuma ve yazma) & 8 & Literacy skill (Okuryazarlık becerisi) & 6 \\
\hline Foreign language(Yabancı dil) & 8 & Vocabulary learning (Sözcük öğrenme) & 6 \\
\hline
\end{tabular}

Tabloda yer alan morfolojik farkındalık; kelimelerin yapısı (kök, ek), birleșimleri hakkında bilgi sahibi olmayı ifade etmektedir. Bu noktada kök, eklerin dil bilgisel işlevlerini bilme, dil bilgisi kurallarına hakim olma, eklerin farklı durumlarda farklı anlamlar ortaya çıkarabileceğinin farkında olma önemlidir (Memiş, 2019).

Yürütücü fonksiyonlar, kişinin var olan davranış biçimlerini veya alışılmadık, yeni durumlara karşı yaklaşımını belirleyen, yeni bir duruma uyum sağlamaya yardımcı olan üst düzey bilişsel becerilerdir. Bu beceriler planlama, yönetme, dikkati sürdürme ve organize olma gibi yetenekleri içinde barındırmaktadır (Akyürek ve Bumin, 2018; Gilbert ve Burgess, 2007). Bu sözcük öbeğinin başlığında yer aldığ çalışmalarda daha çok bu süreçlerde var olan problemlerin çözümüne yönelik araştırmaların yer aldığı görülmüştür.

\section{İkinci Alt Amaca İlişkin Bulgular}

Araştırmanın ikinci alt amacına ilişkin bulgular Tablo 2'de verilmiştir.

Tablo 2

Son Beş Yıl İçinde Makale Başlıklarında En Sık Yer Alan Sözcükler

\begin{tabular}{lcll}
\hline Sözcük & f & Sözcük & f \\
\hline Reading (Okuma) & 206 & Spelling + orthographic (Yazım, imla) \\
Writing (Yazma) & 153 & Skill (Beceri) & 61 \\
Children (Çocuk) & 86 & Text (Metin) \\
Comprehension (Anlama) & 86 & Chinese (Çinli, Çince) \\
Language/ Languages (Dil) & 75 & English (İngiliz, İngilizce) \\
Grade (Sınıf, aşama) & 74 & İnstruction (Öğretme) \\
Effect (Etki) & 66 & Awareness (Farkındalık) \\
Student/ students (Öğrenci/ öğrenciler) & 64 & Development (Gelişim) \\
Word (Sözcük) & 64 & Learning (Öğrenme) \\
\hline
\end{tabular}


Tablo 2'nin devamı...

\begin{tabular}{llll}
\hline Sözcük & f & Sözcük & f \\
\hline Knowledge (Bilgi) & 38 & Reader (Okur) & 30 \\
Vocabulary (Kelime hazinesi) & 37 & Teacher (Öğretmen) & 28 \\
Study (Çalışma) & 37 & Phonological (Fonolojik) & 26 \\
Morphological (Morfolojik) & 37 & Written (Yazılı olan) & 21 \\
Literacy (Okuryazarlık) & 33 & Fluency (Akıcılık) & 20 \\
Learner (Öğgrenen kimse) & 31 & Handwriting (El yazısı) & 19 \\
\hline
\end{tabular}

Tablo 2 incelendiğinde toplam 6.649 sözcük içerisinde derginin adında da yer alan okuma ve yazmanın makale başlıklarında en fazla ele alınan kavramlar olduğu görülmüştür. Dergide yayımlanmış olan makale başlıklarında okuma becerisi, yazma becerisine göre daha fazla yer almıştır. Buradan yola çıkarak araştırmacıların, okuma alanında yaşanan güçlüklerin giderilmesine, yazmaya göre daha fazla ağırlık verdiği yorumu yapılabilir.

\section{Üçüncü Alt Amaca İlişkin Bulgular}

Araştırmanın üçüncü alt amacına ilişkin bulgular Tablo 3 'te verilmiştir.

Tablo 3

2016 Yılındaki Makale Başlıklarında En Sık Yer Alan Sözcükler

\begin{tabular}{llll}
\hline Sözcük Grubu & f & Sözcük Grubu & f \\
\hline Reading comprehension (Okuduğunu anlama) & 8 & School student (Okul öğrencisi) \\
Morphological awareness (Morfolojik farkındalık) & 4 & Teaching writing (Yazma öğretimi) \\
Lexical quality (Sözlük kalitesi) & 4 & Common core (Ortak öz) \\
$\begin{array}{l}\text { Source information (Kaynak bilgisi) } \\
\text { Middle school (Ortaokul) }\end{array}$ & 4 & National survey (Ulusal araştırma)
\end{tabular}

Derginin 2016 yılına ait 29. cildinde 86 makale bulunmakta ve bu makale başlıklarında toplam 1109 sözcük kullanılmıştır. Tablo 3’ten yola çıkılarak 2016 senesine ait yayımlanan makale başlıklarında, en sık yer alan iki sözcük öbeğinin son beş yıla ait genel tabloyla uyumlu olduğu görülmektedir. Ancak 2016 yılında sözlük kalitesi ve kaynak bilgisinin ele alındığı çalışmalara diğer yıllara göre daha fazla yer verildiği, bu kavramlara eğilim gösterildiği yorumu yapılabilir.

“Ortak öz” ifadesinin 2016’da yayımlanan makale başlıklarından üçünde yer aldığ1 görülmüştür. Ortak öz (Common core) Amerika Birleşik Devletleri’nde herhangi bir öğrencinin liseden mezun olana kadar (K-12) ilkokuldan itibaren her sınıf düzeyinde İngilizce ve matematikte bilmesi gerekenleri ayrıntılarıyla anlatan, belirli standartların oluşturulduğu bir eğitim girişimidir (Corestandarts, 2021).

\section{Dördüncü Alt Amaca İlişkin Bulgular}

Araştırmanın dördünü alt amacına ilişkin bulgular Tablo 4'te verilmiştir.

Tablo 4

2017 Yılındaki Makale Başlıklarında En Sık Yer Alan Sözcükler

\begin{tabular}{lcll}
\hline Sözcïk Grubu & f & Sözcük Grubu \\
\hline Reading comprehension (Okuduğunu anlama) & 11 & Second language (İkinci dil) \\
Word reading (Sözcük okuma) & 5 & Children’s reading (Çocukların okuması) \\
Reading fluency (Akıcı okuma) & 5 & Oral reading (Sesli okuma) \\
Working memory (Kısa süreli bellek) & 4 & Language skill (Dil becerisi) \\
Word recognition (Sözcük tanıma) & 3 & Longitudinal study (Boylamsal çalışma) \\
\hline
\end{tabular}


Derginin 2017 yılına ait 30. cildinde 96 makale bulunmakta ve bu makale başlıklarında toplam 1318 sözcük kullanılmıştır. Tablo 4 incelendiğinde bu ciltte yer alan çalışmalarda öne çıkan okuduğunu anlama, sözcük okuma ve akıcı okumaya yönelik çalışmaların son beş yıldaki verilerin yer aldığı Tablo 1 ile uyumlu olduğu gözlenmiştir.

Derginin bu cildinde üç makalenin boylamsal çalışma türünde olduğu görülmüştür. İncelenen olgu ya da araştırma değişkenlerine ilişkin verilerin farklı zamanlarda toplanması yoluyla el alınan olguda meydana gelen değişimin ve gelişimin tespit edildiği çalışmalar boylamsal çalışma olarak adlandırılmaktadır. Eğitim fakültelerinde 1. sınıfa başlayan öğretmen adaylarının 2., 3. ve 4. sınıfta değișen öğretmenlik kimlik algılarının değișimi bu araștırma türüne örnek gösterilebilir (Özmantar, 2019).

\section{Beşinci Alt Amaca İlişkin Bulgular}

Araştırmanın beşinci alt amacına ilişkin bulgular Tablo 5 'te verilmiştir.

Tablo 5

2018 Yılındaki Makale Başlıklarında En Sik Yer Alan Sözcükler

\begin{tabular}{lcll}
\hline Sözcïk Grubu & f & Sözcük Grubu & f \\
\hline Morphological awareness (Morfolojik farkındalık) & 11 & Language learner (Dil öğrenen) \\
Reading comprehension (Okuduğunu anlama) & 10 & Struggling reader (Güçlük çeken okur) \\
$\begin{array}{l}\text { Text structure (Metin yapısı) } \\
\text { Word reading (Sözcük okuma) }\end{array}$ & 70 & Reading and writing (Okuma ve yazma) \\
Chinese- English bilingual (Çince-İngilizce çift dilli) & 4 & $\begin{array}{l}\text { Linguistic knowledge (Dilbilimsel bilgi) } \\
\text { dilbilimguistic knowledge (Birden fazla dile ait }\end{array}$ \\
\hline
\end{tabular}

2018 yılına ait derginin 31. cildinde 93 makale bulunmakta ve bu makale başlıklarında toplam 1309 sözcük kullanılmıştır. Tablo 1 ile Tablo 5 kıyaslandığında “Güçlük çeken okur” ifadesinin son beş yıl içerisinde toplam altı makalede yer alırken sadece 2018'de üç makale başlığında yer aldığı görülmüştür. Buradan yola çıkılarak diğer yıllara göre 2018 yılında bu konuya eğilindiği yorumu yapılabilir. 31.ciltte bu kavramın yer aldığı çalışmalarda, güçlük çeken okurların özellikle güçlük yaşadıkları metinleri morfolojik, fonolojik veya çeşitli açılardan inceleyen ve bu metinleri güçlük yaşayan okurlar için daha da basitleştirmeyi amaçlayan çalışmalara yer verilmiştir. Buna ek olarak başlıklarda "Dilbilimsel bilgi” ifadesinin de öne çıktığı görülmüştür. Başlığında bu ifadenin yer aldığı çalışmaların, öğretmenlerin sahip oldukları dilbilimsel bilgi düzeyine; öğrencinin sahip olduğu dilbilimsel bilginin, çeşitli dil becerileri üzerindeki etkilerine odaklanıldığı görülmüştür. Buna ek olarak başlığında "Metalinguistic knowledge" yer alan çalışmalarda birden fazla dile ve bu dillerin de dilbilimsel bilgisine hakim olan çift dilli çocuklar ile tek dilli çocukların dil becerileri açısından karşılaştırıldığı çalışmaların öne çıktığg görülmüştür.

\section{Altıncı Alt Amaca İlişkin Bulgular}

Araştırmanın altıncı alt amacına ilişkin bulgular Tablo 6' da verilmiştir.

\section{Tablo 6}

2019 Yılındaki Makale Başlıklarında En Sık Yer Alan Sözcükler

\begin{tabular}{|c|c|c|c|}
\hline Sözcük Grubu & f & Sözcük Grubu & $\mathbf{f}$ \\
\hline Reading comprehension (Okuduğunu anlama) & 10 & İndirect effect (Dolaylı etki) & 3 \\
\hline Reading fluency (Akıcı okuma) & 4 & Morphological awareness (Morfolojik farkındalık) & 3 \\
\hline Argumentative writing (Eleştirel yazma) & 4 & Phonological awareness (Fonolojik farkındalık) & 3 \\
\hline Word production (Sözcük üretimi) & 3 & School student (Okul öğrencisi) & 3 \\
\hline Writing difficulties (Yazma güçlükleri) & 3 & Persuasive writing (İkna edici yazma) & 3 \\
\hline
\end{tabular}

Derginin 2019 yılına ait 32. cildinde 99 makale bulunmakta ve bu makale başlıklarında toplam 1405 sözcük kullanılmıştır. Tablo 6 incelendiğinde derginin, 2018 yılında "Güçlük çeken okurlara” yönelik çalışmalara ağırlık vermişken 2019 yılında "Yazma güçlükleri” ile yazma becerisinde güçlük yaşayan çocuklara yönelik araştırmalara ağırlık verdiği yorumu yapılabilir. Ayrıca derginin bu cildinde eleştirel yazmaya ve ikna edici yazmaya da diğer yıllara göre daha fazla ağırlık verildiği görülmektedir.

İkna edici yazma, bir konu üzerinde öne sürülen düşüncelerin gerekçeleriyle birlikte yazılmasıdır. Yazar bu türde düşünce ve değerlerine göre görüş sunar, bunu çeşitli argümanlarla desteklemeye çalışır (Kurudayığlu ve Yılmaz, 2014). 


\section{Yedinci Alt Amaca İlişkin Bulgular}

Araştırmanın yedinci alt amacına ilişkin bulgular Tablo 7'de verilmiştir.

Tablo 7

2020 Yılındaki Makale Başlıklarında En Sık Yer Alan Sözcükler

\begin{tabular}{lcll}
\hline Sözciuk Grubu & f & Sözcük Grubu & f \\
\hline Reading comprehension (Okuduğunu anlama) & 16 & Phonological awareness (Fonolojik farkındalık) \\
Executive function (Yürütücü fonksiyonlar) & 11 & Middle school (Ortaokul) \\
Second grade (İkinci sınıf) & 7 & Oral reading (Sesli okuma) \\
Academic language (Akademik dil) & 5 & Emergent literacy (İlk beliren okuryazarlık) \\
First grade (Birinci sinıf) & 5 & Early reading (Erken okuma) \\
\hline
\end{tabular}

Derginin 2020 yılında yayımlanan 33. cildinde toplam 109 makale bulunmakta ve bu makale başlıklarında ise toplam 1508 sözcük kullanılmıştır. Tablo 7 incelendiğinde dergi başlıklarında sık tekrarlanan sözcük öbeklerinin son beş yıl ile uyumlu olduğu görülmektedir. Başlıklar içinde "Emergent literacy” kavramı dikkat çekmektedir. "İlk beliren okuryazarlık" olarak çevirebileceğimiz bu ifade ile çocukların okuma yazma öğrenmeden önce, bir veya iki yaşından itibaren sahip oldukları okuryazarlık becerileri açıklanmaya çalışmaktadır. Bu düşünceye göre bir çocuğun okuryazarlık becerilerinin, okula başlamadan çok daha önce ortaya çıktığı ve bu becerilerin çocuğun içinde bulunduğu çevreden, bilinçli ya da bilinçsiz olarak gerçekleşen okuma yazma faaliyetlerinden etkilendiği kabul edilmektedir. Bu nedenle ebeveyn ve eğitimciler tarafından yapılacak olan yazılı esere güdüleme, yazılı eser farkındalığı, sözcük becerisi, anlatma becerisi, harf bilgisi ve fonolojik farkındalık çalışmaları ile çocukların ilk beliren okuryazarlık becerilerinin geliştirilmesi ve başarılı bir şekilde erken okuryazarlığa geçmesi amaçlanmaktadır (Whitehurst ve Lonigan, 2003).

\section{Sonuç}

$\mathrm{Bu}$ araştırmada "Reading and Writing" dergisinde son beş yıl içinde yayımlanmış olan makale başlıklarında en sık yer alan sözcük grupları ve sözcükler tespit edilmeye çalışılmıştır. Bu yolla derginin son beş yıl içinde yayımlamış olduğu çalışmalarda hangi kavramlara, konulara ağırlık verdiği tespit edilmeye çalışılmıştır. Toplam 483 makale başlığ incelenmiş ve bu makale başlıklarında yer alan sözcük grupları, sözcüklerin frekansları belirlenmiştir. Dergide yer alan çalışmaların derginin disiplinler arası yaklaşımına uygun olarak derginin kapsadığı alanlarla uyumlu olduğu gözlenmiştir. Elde edilen veriler incelendiğinde son beş yıl içerisinde dergi başlıklarında en sık tekrarlanan sözcük öbeklerinin sırasıyla "Okuduğunu anlama(f:56)", "Morfolojik farkındalık (f:22)" ve "Sözcük okuma (f:17)” olduğu görülmüştür. $\mathrm{Bu}$ açıdan bakıldığında okuma yazma ile ilgili dergide son beş yılda yayımlanan çalışmalarda araştırmacıların belirgin bir biçimde "okuduğunu anlama” becerisine yönelik çalışmalara ağırlık verdiği görülmektedir. Okuduğunu anlama becerisinin, öğrencinin yaşamı boyunca tüm öğrenmelerini etkilemesi, belirlemesi sebebiyle araştırmacıların buna yönelik çalışmalara ağırlık verdiği yorumu yapılabilir. Ayrıca son beş yılda yayımlanan makalelerde ilkokul düzeyindeki çalıșmalara da diğer kademelere göre daha fazla yer verildiği tespit edilmiștir. İlkokul döneminin okuma ve yazma becerisinin ediniminde kritik öneme sahip olması sebebiyle bu farklılaşmanın ortaya çıktığı düşünülmektedir.

Sözcük bakımından incelendiğinde dergide yayımlanan çalışmalarda, okuma ve yazma becerilerine eşit miktarda yer verilmediği gözlenmiştir. Yayımlanan makale başlıklarından yola çıkılarak derginin okumaya yönelik çalışmalara daha fazla yer verdiği görülmüştür.

Elde edilen veriler yıllara göre incelendiğinde ise bazı sözcük gruplarının belirli yıllarda diğer yıllara göre makale başlıklarında daha fazla yer aldı̆̆ı görülmüştür. Örneğin, 2016 yılında "Sözlük kalitesi”, "Kaynak bilgisi”; 2018 yılında "Güçlük çeken okur", "Dilbilimsel bilgi”, "Birden fazla dile ait dilbilimsel bilgi (Metalinguistic knowledge); 2019 y1lında "Yazma güçlükleri”, "Güçlük çeken okur”; 2020 yılında "İlk beliren okuryazarlık (Emergent literacy)" sözcük gruplarının diğer yıllara göre başlıklarda daha sık yer aldığı tespit edilmiştir. Bu açıdan bakıldığında dergide yer alan makalelerde ele alınan kavramların yıllara göre farklılaşma gösterdiği söylenebilir.

Elde edilen veriler ışı̆̆ında "Reading and Writing" dergisinde son beş yıl içerisinde makale başlıklarında en sık tekrarlanan sözcük öbeklerinin, sözcüklerin belirlendiği bu çalışma dünyada okuma ve yazma alanında son yıllarda hangi kavramlara odaklanıldığını, yabancı alanyazının hangi yönde ilerlediğini göstermesi bakımından önemlidir. Bulgular ışığında dergide öne çıkan okuduğunu anlama, morfolojik farkındalık, sözcük okuma ile birlikte yürütücü fonksiyonlar, akademik dil, çift dillilik ve erken okumaya yönelik çalışmalar yapılması önerilmektedir. Çalışmaların uygulayıcısı olan Türkçe öğretmenlerinin alanlarına ilişkin akademik dergileri takip etmelerinin ve edindikleri bilgilere ilişkin derslerinde uygulamalar yapmalarının hem kendilerine hem de öğrencilerinin dil gelişimine katkı sağlayacağı düşünülmektedir. 


\section{Kaynakça}

Akyürek, G., Bumin, G. (2018). Disleksili Çocuklarda Ev Okuryazarlık Ortamı Ve Aktivite Rutinleri. Bozok Tip Dergisi, 8(3), 16-23.

Arıc1, A.F. (2008). Okuma Eğitimi. Ankara: Pegem.

Aytaş, G. (2003). Okuma Gelişiminde Çocuk Edebiyatının Rolü. Türklük Bilimi Araştırmaları, (13), 155-160.

Aytaş, G. (2005). Okuma Eğitimi. Türk Eğitim Bilimleri Dergisi, 3(4), 461-470.

Baddeley, A.D., Thomson, N., Buchanan, M. (1975). Word Length And The Structure Of Short-Term Memory. Journal of Verbal Learning And Verbal Behavior, (14), 575-589.

Balcı, A. (2010). Sosyal Bilimlerde Araştırma. Ankara: Pegem Akademi.

Baştuğ, M., Hiğde, A., Çam, E., Örs, E., Efe, P. (2019). Okuduğunu Anlama Becerileri Geliştirme Stratejiler, Teknikler, Uygulamalar. Ankara: Pegem Akademi.

Büyüköztürk, Ş., Kılıç Çakmak, E., Akgün, Ö., Karadeniz, Ş., \& Demirel, F. (2012). Bilimsel Araştırma Yöntemleri. Ankara: Pegem Akademi.

Cansoy, R., Türkoğlu, M. E. (2019). Verilerden Anlam İnşa Etme Süreci. Turan, S. (Ed.), Eğitimde Araştırma Yöntemleri. Ankara: Nobel.

Chomsky, N. (2016). Doğa ve Dil Üzerine. (Çev. A.B. Karadağ). İstanbul: Sözcükler.

Corestandarts (2021). About The Standarts. http://www.corestandards.org/ adresinden alındı.

Coşkun, E. (2002). Okumanın Hayatımızdaki Yeri ve Okuma Sürecinin Oluşumu. Türklük Bilimi Araştırmaları, (11), 231-244.

Coşkun, E. (2013). Yazma Eğitiminde Aşamalı Gelişim. Özbay, M. (Ed.), Yazma Eğitimi. Ankara: Pegem Akademi.

Dilidüzgün, Ş. (2014). Türkçe Öğretiminde Sözcük Öğretme Yöntemlerinin Yeterliliği. Adıyaman Üniversitesi Sosyal Bilimler Enstitüsü Dergisi, 7(17), 233-258.

Ergin, M. (2011). Türk Dil Bilgisi. İstanbul: Bayrak.

Fischer, S. R. (2020). Dilin Tarihi. İstanbul: Türkiye İş Bankası Kültür Yayınları.

Fraenkel, J. R., Wallen, N. E. (2006). How to Design and Evaluate Research in Education (6 b.). San Francisco: Mc Graw Hill.

Gilbert, S.J., Burgess, P.W. (2007). Executive Functions. Current Biology, 18(3), 110-114.

Henniger, M.L. (2005). Teaching Young Children. New Jersey: Pearson Education.

Karadüz, A. (2009). Sözlük, Sözcük Anlamı ve Öğrenme Üzerine. Turkish Studies, 4(4), 636-649.

Kurudayığlu, M. ve Yılmaz, E. (2014). Türkçe Öğretmeni Adaylarının Oluşturdukları İkna Edici Metinlerin Yapı Açısından İncelenmesi. Okuma Yazma Eğitimi Araştırmaları, 2(1), 20-29.

Memiş, M. R. (2019). Morfolojik Farkındalık ve Morfolojik Farkındalık Eğitimi. Uluslararası Türkçe Edebiyat Kültür Eğitim Dergisi, 8(3), 1355-1368.

Morton, J. (1969). Interection of Information in Word Recognation. Psychological Review, 76(2). 165-178.

Özbay, M. ve Memiş, M. R. (2015). Beyin Araştırmalarına Dayalı Öğrenme ve Yazma Eğitimi. Ana Dili Eğitimi Dergisi, 3(2), 1-34.

Özge, D. (2016). Çocuklarda Dil Anlama Süreçleri. Alpöz, R. (Ed.), Aklın Çocuk Hali: Zihin Gelişimi Araştırmaları. İstanbul: Koç Üniversitesi Yayınları.

Özmantar, Z. K. (2019). Eğitim Çalışmalarında Sık Kullanılan Araştırma Türleri. Turan, S. (Ed.), Eğitimde Araştırma Yöntemleri. Ankara: Nobel.

Razı, S. (2008). Okuma Becerisi Öğretimi ve Değerlendirilmesi. İstanbul: Kriter.

Sav, B. (2003). Anlam Değişmeleri Üzerine Artzamanlı Bir İnceleme. Gazi Eğitim Fakültesi Dergisi, 23(1), 147-166.

Savaş, B. (2006). Okuma Eğitimi ve Çocuklarda Dil Gelişimi. İstanbul: Alfa.

Springer (2021). Reading and Writing Aims and Scope. https://www.springer.com/journal/11145/aims-and-scope adresinden alınd.

Temizkan, M. (2010). Türkçe Öğretiminde Yaratıcı Yazma Becerilerinin Geliştirilmesi. Türklük Bilimi Araştırmaları, (27), 621-643.

Thornbury, S. (2013). How to Teach Vocabulary. Harlow: Pearson Education Limited. 
Türk Dil Kurumu. (2005). Türkçe Sözlük. Ankara: Türk Dil Kurumu Yayınları.

ULAKBİM (2021). https://ulakbim.tubitak.gov.tr/tr/haber/tubitak-2020-ubyt-programi-ve-dergi-listesi-ilan-edildi adresinden alınd.

Uslu Üstten, A. (2019). Okuma Eğitiminin Temel Kavramları. Şen, Ü. (Ed.), Dil Eğitiminin Temel Kavramları (s.61-87). Ankara: Pegem Akademi.

Web of Science (2021). https://mjl.clarivate.com/ adresinden alındi.

Whitehurst, G.J., Lonigan, C.J. (2003). Emergent Literacy: Development from Prereaders to Readers. Neuman, S.B. \& Dickinson D.K. (Ed.), Handbook of Early Literacy Research. New York: The Guilford Press.

Yıldız, C. (2003). Türkçe Öğretiminde Alternatif Yöntemler. Ankara: Anı. 